\title{
DOCTOR-PATIENT COMMUNICATION: TOWARDS AN OUTLINE OF MEDICAL ENGLISH DIDACTICS
}

\author{
JANINA WIERTLEWSKA
}

\section{Introduction}

ESP (English for Specific Purposes, including Medical ESP) is characterized by Hutchinson and Waters as an approach to foreign language didactics (see: DoneschJeżo, 2013; Hutchinson and Waters, 1987). The following citation comprises the substance of ESP:

ESP is not a special kind of a given language or a methodology, either a special mode of teaching material. To be precise - it is an approach to a foreign language teaching based on the requirements of the students. The basis of ESP is formed by a simple question: "What does a given person learn that language for?". [...] ESP is an approach to foreign language teaching, in which all the decisions concerning the contents and teaching methods are built upon the reasons for which the formerly every person is learning the foreign language (Donesch-Jeżo, 2013: 17, after Hutchinson and Waters, 1987: 19, English transl. J.W.).

In the last 20 years the analysis of the academic discourse had to pave its way for the field of medical training of future doctors. Following Donesch-Jeżo's (2013) reasoning and her definition of the academic discourse which is cited as follows: „The notion of academic discourse is associated with the mode of thinking and use of the (English) language in the academic community (see: Hyland, 2004; 2009; 2011), and with the idea of the language in question going far beyond the structure of a single sentence and providing an elaborate communication act between a sender 
and a receiver of a given message" (Donesch-Jeżo, 2013: 7; Paltridge, 2013 - English transl. J.W.). A lecturer of the ESP (medical English) may come to the conclusion that structuring the course for medical students demands a very thoughtful choice on his/her part: whether to teach the practical discourse (mainly doctorpatient communication) or rather choose the academic writing which, in turn is necessary in unveiling research either in a form of a written text or a multi- media presentation. It is extremely important to analyse the goals and needs of the students and future doctors before preparing the syllabus for medical English tutorials, as English became lingua franca or "lingua globalis" (Puppel, 2014: 142) of all professionals, including medical professionals who are involved in medical research starting early in their lives, still as students of medicine. In my work with medical students I structure the course in such a way that $75 \%$ of the tutorials are devoted to doctor-patient verbal and non-verbal communication and $25 \%$ - to academic writing.

\section{Some remarks on communication}

Investigations of human communication became an important scientific field in the USA as well as in the West European countries after the World War II. In Poland this issue appeared as a research problem in the so-called transformation period at the end of the 1980s and the beginning of the 1990s of the twentieth century and presently it constitutes a dynamically developing multidisciplinary scientific field. Fiske (1998) in his work entitled "Introduction to Communication Studies" formulates a general definition of communication which he determines as "...a sort of social interaction through transmission of messages" (Fiske, 1998, Polish $2^{\text {nd }}$ edition, 2008: 16; Wiertlewska 2012; 2014 - Engl. transl. J.W.). Since that time many definitions of communication have been constructed. The definition of communication that conforms to my notion of communication is presented in the follow-up citation and was phrased by three co-authors: Frey, Botan and Kreps (2000): "Communication is a process of information organizing aiming at creation of meaning. The key terms constituting the definition of communication are: messages, organizing and meaning" (Morreale, Spitzberg and Bange, 2007: 37, Wiertlewska, 2014; 2017a in press. - Engl. transl. J.W.). Looking at a communication process from a generalized perspective the following components: Participants of a communication process: Sender and Receiver, Messages, Channel and Feedback are distinguished. Fiske (1994, see: Good Practice, 2008 9) presents a different from the formerly mentioned one model of communication which he established especially for the professional space of doctor-patient communication. The chart below presents the five components of doctor-patient communication according to Fiske (verbal and non-verbal communication, vice management, active listening, cultural awareness): (1994, Mc Cullagh and Wright, 2008: 9). 


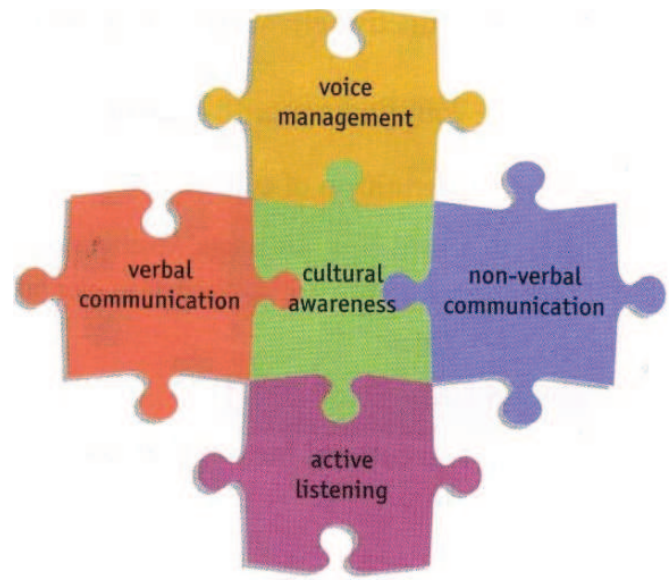

Chart 1. The five components of medical communication according to Fiske (1994; cited in McCullagh and Wright, 2008: 9).

\section{Ecology of language (ecolinguistics)}

The word "ecology" is derived from the following Greek words: "oikos" meaning "home", a place to live in and "logos" meaning - investigating or studying. It was coined in 1866 by a German biologist, Ernst Hackel (see: "Stanford Encyclopaedia of Philosophy Online", 2017). Ecology can be described following Odum's concept (2000) in such a way that it comprises investigating and studying the structure and functions of nature and its environment. "Structure" in Odum's reasoning means patterns of arrangement and an enormous number of organisms, while "function" refers to interactions occurring between populations among which the following processes can be mentioned: competition, symbiosis and cycles of energy exchange. The notion of "environment" in the previously mentioned context comprised the fields of culture, society, politics, economics and biology. The term "environment" of a given organism includes physical properties which may be described as a sum of biotic and abiotic factors characteristic for a given area such as climate, geological factors and also other organisms inhabiting the same habitat. Ecology is considered to be a multidisciplinary field of science as in its investigations it takes into consideration higher levels of organization of various forms of life on earth as well as the mutual relations taking place between organisms and their environments. Ecology is based on numerous branches of science, particularly on geology, geography, meteorology, chemistry and physics. Thus it becomes a science of a holistic character, being ranked higher than the older disciplines (e.g. biology); biology, in turn becomes a scientific sub-discipline making its contribution to the extensive ecological knowledge (see: Krebs, 1972; 2006; Wiertlewska, 2014; 2017 in press). The term "ecosystem" is one of those which characterize ecology. Some researchers 
consider this notion to be of the fundamental importance in ecology. Ecosystem constitutes a basic ecological unit consisting of a biotic community and environment surrounding it. The main doctrine of ecology is expressed in the fact that every living organism remains in a continuous relationship with every component of the environment that a given organism inhabits. Ecosystems are not separated from each other but are rather associated with one another (Smith, 1996; Puppel, 2007; Wiertlewska, 2014). The term ecosystem has also been used in the field of linguistics. Ecology of language (or ecolinguistics) is a multidisciplinary and a particularly new notion in linguistics which is linked with different fields of human life such as: economics, sociology, politics, geography, anthropology and education. Many scholars including: Hymes (1964), Gumperz (1964), Haugen (1966), Lennenberg (1967), Mackey (1980), Weinrich (1990), Schultz (1992), Berman (1994) and Harris (2001) participated in the delineation of assumptions of ecolinguistics by pointing out the correlations occurring between a language and its environment. Ecology of language or ecolinguistics appeared as a new branch of science in the 1990s of the $20^{\text {th }}$ century. It took into consideration not only the social context in which the languages were embedded but also the ecological context in which the whole societies functioned. M.A.K. Halliday's (1990) article entitled "New ways of meaning: the challenge to applied linguistics" was recognized as an absolutely innovative work which gave the linguists an impulse for investigating languages in the ecological perspective. The challenge which Halliday posed in front of linguists aimed at causing linguistics to start developing in the direction essential for the $21^{\text {st }}$ century issues, that is - an enormous destruction of ecosystems. Since the time when Halliday presented his opinions, the scientific field of ecolinguistics has developed markedly and lately it has been applied both in education and in the fight for linguistic sustainability (see: Wiertlewska, 2014; 2016; 2017a in press). Ecolinguistics is divided into two following fundamental sections:

- ecology of language

- eco-critical discourse analysis (see: Fill, 1996; Steffensen, 2007; Wiertlewska, 2014).

Einar Haugen, a Norwegian linguist, the professor of Harvard and Wisconsin Universities, who investigated the Scandinavian languages is considered to be the pioneer in the field of ecology of language. Ecology of language or ecolinguistics uses the metaphor of the word ecosystem in order to describe associations and interactions occurring between various languages that are spoken in the world and also between groups of people which use these languages. The so-called "healthy ecology of language" including an enormous amount of various linguistic forms is perceived as an essential issue in the "healthy ecosystems", as the knowledge concerning local ecological systems builds into local language diversities (see: Mühlhausler, 1995; Wiertlewska, 2014). In Haugen's opinion every language can be best understood in its social context. Such a context is necessary for determining conditions for the first language acquisition by a little child. Moreover, the social context specifies 
situations in which the application of certain linguistic forms is more or less suitable. The formerly mentioned view of the issue of ecology of language determines relations between speech and a written form of a language and the circumstances of occurrence of discourse. Haugen's definition of ecology of language in which the author distinguishes environmental interactions refers to external relations between a language and its environment which is well expressed in the following citation:

A part of language ecology is psychological in its nature - these are the interactions with other languages taking place in minds of bi- and multilingual individuals. Another part of it is sociological: this is constituted by the interactions within the society in which the language functions as a means of communication. (Haugen cited in: Fill and Mühlhausler, 2001: 57)

By introducing the notion of ecology of language with reference to mutual relations occurring between various languages in human minds living in multilingual societies, Haugen connects linguistics with psychology and sociology which is very important in the perspective of doctor-patient communication didactics. The aim of ecolinguistic investigations is to deliberate on language both in its spoken and written forms in accordance with what Haugen (1970) calls intra-relations, interrelations or extra-relations. Ecolinguists assume that language is not an autonomic field and that is why they do not examine it as a system. They present the opinion that there exist mutual relations between linguistic structures (units) as well as between these units and their environments which leads to the formation of external linguistic relations perceived as being dynamic and globally acting ones. Environment in ecolinguistics occupies a very high-rank position. The notion of environment which goes far beyond the field of biology has been extended markedly in the recent years and presently it comprises the following: pollution, endangerment, biological diversity, technology and many others. The mutual relations occurring between particular languages and the environment enabled establishing the remedial programmes for endangered languages and combination of language and sociology caused that ecolinguistics started to be considered as a life science (see: Bang and Door, 2000; Wiertlewska, 2014) as human beings, not speaking machines or animals are considered to be the subjects of investigations. Before starting the analysis of doctor-patient communication from the ecolinguistic point of view it is necessary to centre upon the eco-critical discourse analysis. Discourse analysis, being a multidisciplinary field of investigations constitutes the branch of science which takes into consideration linguistic and socio-cultural aspects of texts in order to determine how the meaning of a given text is constructed (see: Duszak, 1998; Wiertlewska, 2014). Eco-critical discourse analysis (i.e. ecolinguistic discourse analysis) in turn, comprises the application of critical discourse analysis in order to reveal the fundamental ideologies referring to the texts oriented to environment (see: Harre et al., 1999; Stibbe, 2005; 2006; Wiertlewska, 2014). The formerly mentioned type of analysis 
centres not only on potentially destructive ideologies but also seeks a discourse that could contribute to the maintenance of the possibly greatest number of ecological environments. The ecolinguistic perspective of looking at a language by taking into consideration the social conditions of functioning of a given language and its environment gives possibilities of investigating everything that is associated with a given language in a precise and integrated way (see: Wiertlewska, 2014).

\section{3a.Translingualism versus interlingualism}

In the research field of ecolinguistics two perspectives are distinguished: translingualism and interlingualism. The author of this article follows (after Puppel, 2007) the translingual perspective which is precisely described in the following citation:

The linear placement of two languages may be described as "INTER" - as it allows the possibility of occurrence of competition between the native language (L1) and the second language (L2). The competition often gives a result in a form of ascribing the latter the conscious status of a substratic language by native communicators of a given language (see: Puppel and Puppel, 2005), while the second language achieves the superstratic status... It is harmful to the native language which often, as a result of the external linguopressure on the consciousness level of native communicators, both individual as well as collective is downgraded by them, more or less consciously to the role of a communicative tool of a subordinate status in relation to L2 which is an "invading" language. The negative results of the "INTER"-perspective could possibly be prevented by the application of the "TRANS'-perspective which allows the language contact of a more "characterized" type which means that the latter takes into account participation of less or more developed cultural-linguistic-communicative awareness of native speakers of a given language. The formerly mentioned awareness, should, first of all, comprise the positive attitude of native speakers of any language to this language and to their own cultural-language-communicative community. It is worth stressing that the existence of such a community cannot be established in advance - it has to be intentionally generated "vis a vis" the second language (L2)....so that it could enable the initiation and maintenance at least a minimal programme of the native language use, the so-called "language loyalty use" (Puppel, 2007: 57 - Engl. transl. J.W.).

The Comparison of the two formerly mentioned perspectives is presented below:

1. The "INTER"-perspective puts emphasis on language-communicative skills of the dominant language.

2. The "INTER"-perspective allows the marginalization of a given native language (L1) in the consciousness of native speakers of this language.

3. The "INTER"-perspective does not create favourable conditions for linguistic diversity maintenance. 
4. The "TRANS"-perspective helps the native communicators of a given language to acquire the highest possible level of the cultural-language-communicative competence in the scope of L2 and simultaneously it requires from the native communicators the improvement of cultural-linguistic-communicative competence and skills in the scope of L1 - the native language.

5. The "TRANS"-perspective leads to multilingualism on the level of individual native speakers as well as the whole national and ethnic communities.

6. The "TRANS"-perspective creates an opportunity for ecological sustaining of the highest possible number of natural languages.

In my opinion the handbook written by Marie McCullagh and Ros Wright (2008) "Good Practice. Communication Skills in English for the Medical Practitioner" is the best example of how to teach and learn doctor-patient communication in English in the ecolinguistically sustainable perspective. I analyzed the formerly mentioned handbook from the point of view of an ecolinguist and a tutor of medical English at Collegium Medicum in Bydgoszcz, Nicolaus Copernicus University in Toruń, and present the outcomes of my investigations below.

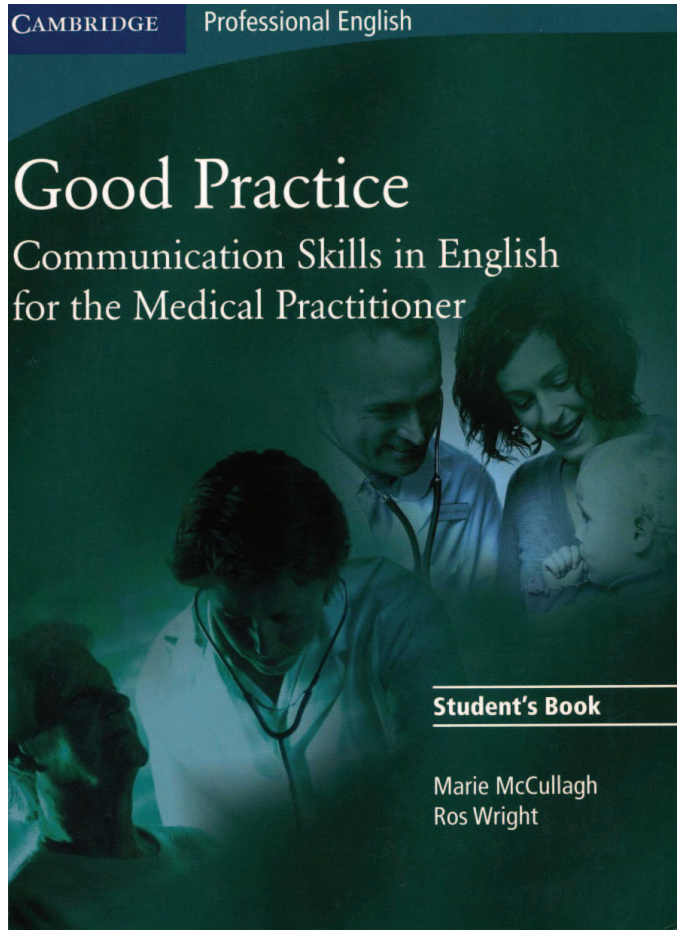

Chart 2. The cover of "Good Practice" student's book (Mc Cullagh and Wright, 2008)

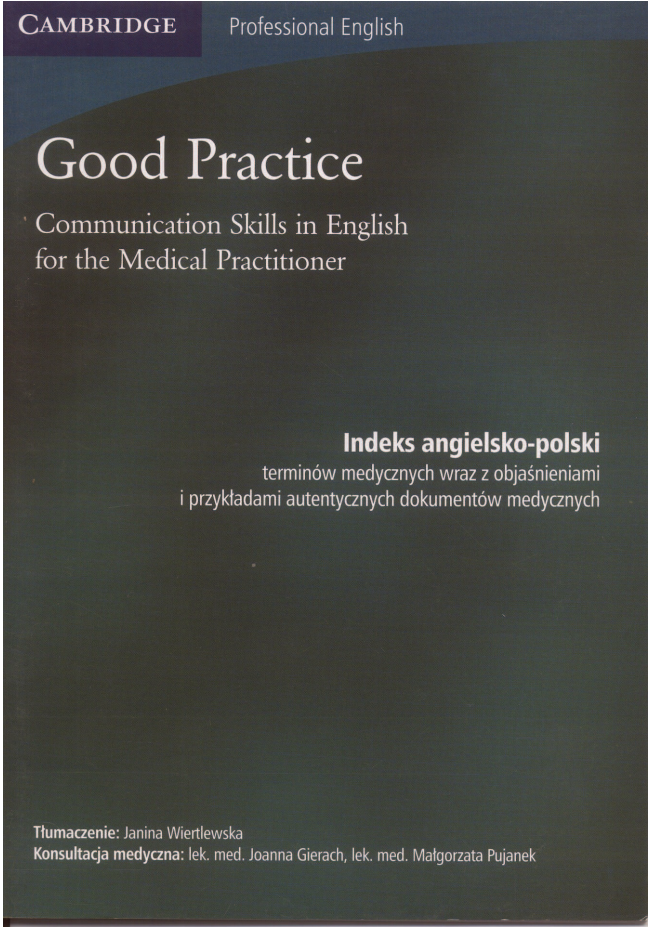

Chart 3. The cover of the Polish-English glossary Indeks angielsko-polski accompanying "Good Practice” handbook (Wiertlewska, 2008) 
The course "Good Practice" consists of the student's book accompanied by the English-Polish glossary book and the teacher's book. Two audio-cassettes and a DVD are also available with this course. I happen to be the interpreter of the glossary book. After a few years of teaching experience with this book I came to the conclusion that the vocabulary contained in the glossary should be extended in order to make it more comprehensible to the students and also - to make it more ecolinguistically balanced in order to protect linguistic sustainability.

\section{Ecolinguistic sustainability}

The issue of ecolinguistics is closely related to the notion of ecolinguistic sustainability. One of the scholars who explain it plainly is Bastardas-Boada (2014). According to Bastardas-Boada (2014):

The concept of sustainability comes... from the tradition of thinking that criticises the perspective of economic development that overlooks almost totally the natural environment - the precise context where this development takes place and which thus leads it to a final end devoid of resources and clearly harmful for the life of human beings... Against this economic view, some academic and activist enclaves have proposed the perspective of "sustainable development" or "lasting development" (Bastardas-Boada, 2014: 135).

Bastardas-Boada (2014) states that sustainability emphasizes safeguarding of the natural environment from the ecological point of view. As we follow the formerly mentioned academic's reasoning, we may come to the conclusion that linguistic sustainability incorporates both the expansion of the dominating languages and maintenance of the linguistic diversity. As the scholar says: "An ecological perspective on linguistic diversity would have aim to stop and reverse expansionist and dominating ideologies. Passing into another historical phase of humankind where predominant vision would be one of recognising equal dignity of all languages and linguistic groups (Bastardas-Boada, 2014: 137). Accepting fully Bastards-Boadas mode of reasoning associated with the presently discussed problem I cite after the distinguished scholar that: "The ecology of languages should be of socio-cognitive holistic approach based on cultural ecosystems and relations among these ecosystems, because the basic unit is not language but always "the language in context" (Bastardas-Boada, 2014: 139). In relation to the formerly mentioned concept of ecolinguistic sustainability selected exercises from the handbook "Good Practice' (McCullagh and Wright, 2008) which contain very specific vocabulary have been chosen as from the point of view of a tutor/ecolinguist they ought to be translated into Polish in order to avoid ambiguity and actively protect linguistic sustainability. 
The arrangement of the environment in doctor's office is ecological when looking at the picture on page 15 in Student's book of the "Good Practice" course (seating arrangements) which visualizes establishing the initial contact between the doctor and the patient. The example taken from the formerly mentioned handbook is presented below.

\section{Establishing initial contact}

The setting for the patient encounter is very important.

4a 1.1 You're going to hear a communications expert talk about the importance of seating arrangements in a consulting room. Listen and choose the best seating arrangement: 1,2 or 3 .

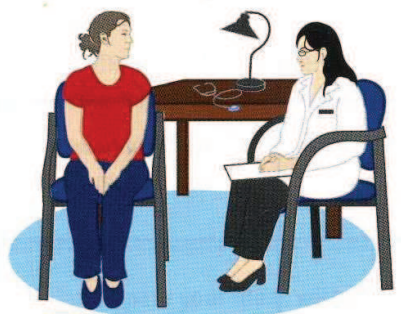

1

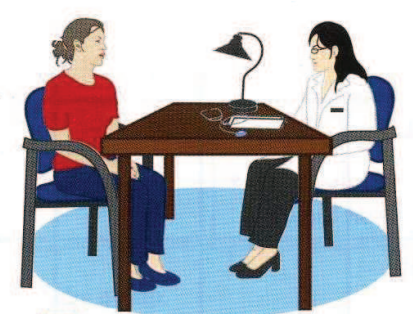

2

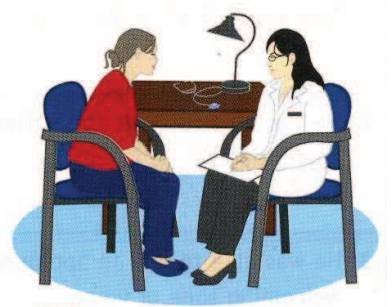

3

Chart 4. "Good Practice, Student's Book”, McCullagh and Wright (2008: 15)

The seating arrangement shown in picture 3 is the most appreciated one and may be called ecological. The language used in this exercise for expressing specific medical issues is also ecological. I dare say that all the discourse contained in this handbook may be described as eco-critical and is characterized by the following features:

- the language used by doctors of all specialties expresses their full acceptance of their patients and it shows how they respect the patients,

- doctors do their best to understand their patients' speech which sometimes is slurred, not precise, filled with specific jargon or dialect,

- doctors treat their patients as partners asking them if they agree to the proposed treatment; they do not impose the treatment on their patients,

- the vocabulary the doctors use while interviewing patients and explaining them the choice of treatment is adapted to the patients' and their families' intellectual levels.

Some examples of translation (my own translation) of specific vocabulary contained in certain exercises of "Good Practice" handbook are presented below. The translation exemplifies the form of linguistic sustainability "in practice". 
UNIT 8 Dealing with sensitive issues

Ex. $15 /$ p. 8. (drug taking) Students are recommended to do the exercise in the following way:

"You might also hear these expressions to describe effects of certain drugs. With

a partner circle language used to describe negative effects and underline language used to describe positive effects."

Students do what they are asked to do but before they start doing anything the tutor ought to equip them with the Polish translation of the English vocabulary, as it is done in the examples below:

- bombed (intoxicated by drink or drugs) - zatruty alkoholem lub narkotykami ("nawalony")

- come down (get sick) - rozchorować się, zwymiotować

- crash (enter uninvited) - wpaść do kogoś bez zaproszenia

- have a bad trip (mentally or psychically horrifying drug-taking experience) - przeżyć coś przerażającego w sensie umysłowym albo psychicznym w związku z przyjęciem narkotyków

- have the shakes (to shake) - mieć dreszcze

- on a high (to feel excitement, pleasure, awesomeness and chilling) - być podekscytowanym, odczuwać przyjemność i strach/grozę jednocześnie wraz z odczuwaniem dreszczy

- spaced out (not completely conscious after taking drugs) - nie być w pełni przytomnym po zażyciu narkotyków

- stoned (under the influence of narcotics) - być pod wpływem narkotyków

- wasted (drunk or intoxicated) - pijany lub "naćpany"

- wrecked (very drunk) - być bardzo pijanym

Ex 16/p. 85

Students are asked to do the following:

"What do the following words refer to in drug culture?" Again, it is advisable that the tutor gives the Polish meaning before the students start doing the exercise.

- kick the habit - pozbyć się nałogu

- detox - detoksykacja, odtruwanie organizmu

- clean up - umyć kogoś

- dry out - wytrzeźwieć

- go cold turkey - całkowicie zaprzestać używania szkodliwej substancji

\section{Conclusions}

Concluding, the author of this article would like to stress that ecolinguistically sustainable approach to doctor-patient communication didactics is evolving at a rapid pace presently. Communication between doctors and patients occupies inter- 
est of medical professionals, linguists as well as psychologists. It has become a field of holistic type of research. While concentrating on doctor-patient communication in medical English tutors and lecturers have to take into account the manifold perspective that comprises not only the medical theoretical knowledge but also the cognisance of the individual characteristic of patients which will lead to treating every patient as every doctor's partner (Wiertlewska, 2017b in press).

\section{References}

Bang, Ch. and J. Door. 2000. "Ecology, ethics and communication". Dialectical Linguistics. Odense. University of Odense, Denmark. 53-84.

Bastardas-Boada, A. 2014. "Linguistic sustainability for a multilingual humanity". Sustainable Multilingualism 7. 134-163.

Begon, M., Harper, J.L. and C.R. Townsend. 2006. Ecology: from individuals to ecosystems. Oxford: Blackwell Publishing.

Berman, T. 2001. "The rape or mother nature. Women in the environmental discourse". In: Fill, A. and P. Mühlhäusler (eds.). The ecolinguistic reader: language, ecology and environment. New York: Continuum. 258-269.

Bugajski, M. 2006. Język w komunikowaniu. Warszawa: Wydawnictwo Naukowe PWN.

Definition of "Communication". Business Dictionary.com. 2011:1-3, Retrieved from: http://www.busi nessdictionary.com/definition/communication.html [last access: 3 Nov. 2016].

Donesch-Jeżo, E. 2013. Akademicki dyskurs medyczny w językach angielskim i polskim w ujęciu lingwistycznym i metodycznym: Artykut naukowy i jego abstrakt. Kraków. Fundacja Zdrowia Publicznego - Uniwersyteckie Wydawnictwo Medyczne „Vesalius”.

Fairclough, N. 2006. Language and globalization. London/New York: Routledge.

Fill, A. 2001. "Ecolinguistics: state of the art 1998". In: Fill, A. and P. Mühlhausler (eds.). The ecolinguistic reader: language, ecology and environment. New York: Continuum. 43-53.

Fiske, J. 1994. Introduction to communication studies. London: Routledge.

Griffin, E. 2001. A first look at communication theory. New York: McGraw Hill Companies.

Gordon, T. and W.S. Edwards. 1995. Making the patient your partner. Wesport/Connecticut/London: Auburn House.

Halliday, M.A.K. 1990. "New ways of meaning: The challenge to applied linguistics". Journal of Applied Linguistics 6. 7-36.

Hutchinson, T. and A. Waters. 1987. English for specific purposes: a learning centered approach. Cambridge: Cambridge University Press.

Hyland, K. 2004. Disciplinary discourses. Social interactions in academic writing. Ann Arbor: The University of Michigan Press.

Hyland, K. 2009. Academic discourse. English in a global context. London/New York: Continuum Publishing Group.

Hyland, K. 2011. "Academic discourse”. In: Hyland, K. and B. Paltridge (eds.). Continuum companion to discourse analysis. New York: Continuum.

Haugen, E. 1996. Language conflict and language planning: the case of modern Norwegian. Cambridge, MA: Harvard University Press.

Haugen, E. 2001. "The ecology of language". In: Fill, A. and P. Mühlhausler (eds.). The ecolinguistic reader: language, ecology and environment. New York: Continuum. 57-66. 
Lennenberg, E.H. 1967. Biological foundations of language. New York: John Whiley and Sons.

McCullugh, M. and R. Wright. 2008. GOOD PRACTICE. Communication skills in English for the medical practitioner. Cambridge: Cambridge University Press.

Morreale, S.P., Spitzberg, B.H. and J.K. Barge. 2007. Komunikacja między ludźmi. Warszawa: Wydawnictwo Naukowe PWN.

Paltridge, B. and S. Starfield (eds.). 2013. The handbook of English for specific purposes. Boston: Wiley-Blackwell.

Puppel, S. and J. Puppel. 2005. „Zagadnienie percepcji języka naturalnego w triadzie: język ojczysty język globalny - język sąsiedni na przykładzie triady: język polski - język angielski - język niemiecki w ujęciu ekolingwistycznym: próba typologii”. Scripta Neophilologica Posnaniensia 7. 55-59.

Puppel, S. 2007. „Interlingwalizm czy translingwalizm? Interkomunikacja czy trankomunikacja? Uwagi w kontekście współistnienia języków naturalnych w ramach globalnej wspólnoty kulturowojęzykowo-komunikacyjnej”. In: Puppel, S. (red.). Społeczeństwo-kultura-język. W stronę interakcyjnej architektury komunikacji. Poznań: Katedra Ekokomunikacji UAM. 79-94.

Puppel, S. 2014. "Multis vocibus de lingua anglica: towards an outline of an emotional profile of English as a major globalizing natural language of today". Scripta Neophilologica Posnaniensia 10. 139-148.

Stanford Encyclopaedia of Philosophy. Ecology of language. Retrieved from: https//www.qz.com [last access: 11 Jan. 2017].

Wiertlewska, J. 2008. Indeks angielsko-polski - a companion to: good practice. communication skills for a medical practitioner. Cambridge: Cambridge University Press.

Wiertlewska, J. 2012. "Communication in the ecological perspective”. In: Koszko, M., Kowalewska, K., Puppel, J. and E. Wąsikiewicz-Firlej (eds.). Lingua nervus rerum humanarum. Poznań. Wydawnictwo Naukowe UAM. 395-409.

Wiertlewska, J. 2014. Ekolingwistyczne podejście do nauczania języków obcych na przykładzie języka angielskiego - wyzwaniem dla glottodydaktyki XXI wieku. Toruń/Bydgoszcz: UMK w Toruniu, Collegium Medicum im. L. Rydygiera w Bydgoszczy.

Wiertlewska, J. 2016. "Linguistic sustainability: an experiment performed on Polish teachers of English measuring their attitude to English, Polish and other foreign languages". In: Bielak, M. and J. Taborek (eds.). A dialogic contribution to determinants of glottodidactic space. Piła: Państwowa Wyższa Szkoła Zawodowa im. S. Staszica. 155-163.

Wiertlewska, J. 2017a (in press). "Linguistically sustainable ESP/Medical English English teaching on the example of Nicolaus Copernicus University, Collegium Medicum in Bydgoszcz”. Kwartalnik Neofilologiczny.

Wiertlewska, J. 2017b (in press). "Is it possible for doctors to treat their patients and communicate with them as if they were their partners?" In: Wiertlewska, J. (ed.). Komunikacja. Dydaktyka języka obcego w szkole wyższej. Toruń/Bydgoszcz: Dział Wydawnictw Collegium Medicum w Bydgoszczy, Uniwersytet Mikołaja Kopernika w Toruniu. 